\title{
Vitamin D Binding Protein Sequesters Monomeric Actin in the Circulation of the Rat
}

\author{
Kristine D. Harper, James F. McLeod, Mary A. Kowalski, and John G. Haddad \\ Endocrine Section, Department of Medicine, University of Pennsylvania School of Medicine, Philadelphia, Pennsylvania 19104
}

\begin{abstract}
Plasma vitamin D binding protein (DBP) may scavenge actin released during cell lysis. We examined the plasma disappearance and tissue appearance of ${ }^{125} \mathrm{I}-\mathrm{DBP},{ }^{125} \mathrm{I}-\mathrm{G}$-actin, and the DBPG-actin complex after their intravenous administration to rats. The plasma disappearance of DBP and DBP-actin were indistinguishable, with rapid initial $\left(t_{1 / 2}=2.6 \mathrm{~h}\right)$ and slower second $\left(t_{1 / 2}=7 \mathrm{~h}\right)$ slopes. After ${ }^{125} \mathrm{I}-\mathrm{G}$-actin (nanomole) injection, plasma disappearance paralleled that of DBP and DBP-actin. All injected actin wass associated with DBP, without evidence of free actin, actin-gelsolin complexes or actin oligomers. Tissue appearances of ${ }^{125}$ I-apolipoprotein (apo) or holo-DBP were similar, with highest accumulations in perfused liver, kidney, and skeletal muscle. Although more complex phenomena (plasma entry of F-actin and intracellular actin binding proteins) would occur in vivo after cell lysis, our results suggest a role for DBP in the sequestration and disposition of actin monomers in the circulation.
\end{abstract}

\section{Introduction}

The human plasma vitamin D-binding protein (DBP) ${ }^{1}$ is a 58,000-D interalpha globulin possessing one sterol binding site per molecule (1-3). 25-hydroxycholecalciferol $\left(25-\mathrm{OHD}_{3}\right)$ is bound with the highest affinity $\left(10^{-8} \mathrm{M}\right)$, but normally occupies $<5 \%$ of available binding sites (4). DBP is synthesized in the liver (5) and is increased during states of estrogen excess (pregnancy, oral contraceptives) and decreased in hypoproteinemic states (6). However, changes in $25-\mathrm{OHD}_{3}$ concentrations have no effect on the DBP concentration in serum. No human, avian, or other mammalian plasma devoid of DBP has been found (7).

Studies of the kinetic behavior of DBP in rabbit (8) and man (9) revealed a plasma $t_{1 / 2}$ that was brief compared with $25-\mathrm{OHD}_{3}$. In the rabbit the half-life of ${ }^{125} \mathrm{I}-\mathrm{DBP}$ was $\sim 40 \mathrm{~h}$, whereas that of $\left[{ }^{3} \mathrm{H}\right] 25-\mathrm{OHD}$ was $11 \mathrm{~d}(8)$. DBP normally circulates in high concentrations in the plasma of rats and man $(4,10)$ with concentrations of 5-8 $\mu \mathrm{M}(11,12)$. DBPs plasma concentration is 50-100-fold greater than its sterol ligands (8). The calculated mean production rate of DBP in humans was $\sim 0.42 \mathrm{mg} / \mathrm{kg}$ body wt per $h(9)$, indicating DBP to be a high capacity system for the $25-\mathrm{OHD}_{3}$ ligand.

\footnotetext{
Address reprint requests to Dr. Harper.

Received for publication 11 August 1986 and in revised form 2 December 1986.
}

1. Abbreviations used in this paper: apo, apolipoprotein; DBP, vitamin D-binding protein; RSA, rat serum albumin.

J. Clin. Invest.

(c) The American Society for Clinical Investigation, Inc. 0021-9738/87/05/1365/06 \$1.00

Volume 79, May 1987, 1365-1370
In addition to its sterol binding and transport role, plasma DBP has been found to bind monomeric actin (G-actin) in an equimolar ratio (11) with high affinity $\left(10^{-9} \mathrm{M}\right)(13-15)$. Plasma gelsolin, a 93,000-D calcium dependent actin binding protein, binds $\mathrm{G}$-actin in a 1:2 $\mathrm{M}$ ratio (16). Gelsolin severs F-actin filaments in the presence of calcium, whereas DBP inhibits polymerization of G-actin to F-actin $(5,16,17)$.

It has been proposed that plasma gelsolin and DBP might act in concert to scavenge actin released into the circulation after tissue injury, thereby accelerating its plasma clearance, preventing polymerization to F-actin, or disassembling preformed actin filaments $(14,16-18)$.

Accordingly, we examined the plasma disappearance and tissue accumulation of radiolabeled DBP, DBP-actin complex, and G-actin in rats. Our experiments revealed that apolipoprotein (apo) and holo (G-actin)-DBP, and G-actin were cleared rapidly, and that their plasma clearances and tissue appearances were indistinguishable.

\section{Methods}

Materials. All chemicals used were of reagent grade or the best grade available. Bovine serum albumin (BSA), rat serum albumin (RSA), and lactoperoxidase were purchased from Sigma Chemical Co. (St. Louis, MO). Ultra-gel AcA 44 was obtained from LKB Instruments (Gaithersberg, MD). Sodium ${ }^{125}$ I and sodium ${ }^{131}$ I were purchased from Amersham Corp. (Arlington Heights, IL). IgGsorb for immunoprecipitation was obtained from The Enzyme Center, Inc., (Malden, MA). Male SpragueDawley rats were obtained from Charles River Breeding Laboratories (Wilmington, MA).

Procedures. DBP was isolated from rat plasma as previously described (19) and yielded a single band on 7\% sodium dodecyl sulfate (SDS)polyacrylamide gel electrophoresis. DBP was stored at $-20^{\circ} \mathrm{C}$ until used and its concentration determined by the method of Lowry (20) using BSA as the reference standard. G-actin was obtained from rabbit skeletal muscle acetone-dried powder, using the method of Spudich and Watt (21). Before use, G-actin was dialyzed against buffer A ( $0.01 \mathrm{M}$ Tris, 0.2 $\mathrm{mM} \mathrm{CaCl}_{2}, 0.5 \mathrm{mM} \mathrm{Na}-\mathrm{ATP}, \mathrm{pH} 8.0$ ) for 18 to $24 \mathrm{~h}$ and its concentration was determined by its extinction at $290 \mathrm{~nm}$. The actin was always used within $4 \mathrm{~d}$ of its preparation.

Radiolabeling of purified DBP, RSA, and G-actin. $40 \mu \mathrm{g}$ of purified rat plasma DBP and $160 \mu \mathrm{g}$ of G-actin were radiolabeled with ${ }^{125} \mathrm{I}$ using the lactoperoxidase method (22). The ${ }^{125} \mathrm{I}$-DBP was purified by molecular sieve chromatography on a calibrated Ultra-gel AcA 44 column $(2.5$ $\times 60 \mathrm{~cm})$ under constant pump pressure at $4^{\circ} \mathrm{C}$ in $\mathrm{PBS}(150 \mathrm{mM} \mathrm{NaCl}$, $10 \mathrm{mM}$ Na phosphate, $\mathrm{pH} 7.4$ ).

Monomeric, ${ }^{125} \mathrm{I}-\mathrm{G}$-actin, was isolated by filtration on an AcA 44 column $(1.1 \times 60 \mathrm{~cm})$ at $4^{\circ} \mathrm{C}$ under constant pump pressure with buffer A. This radiolabeled G-actin was assessed for its ability to polymerize when $100 \mathrm{mM} \mathrm{KCl}$ and $2 \mathrm{mM} \mathrm{MgCl}$ were added to native G-actin.

Fractions of ${ }^{125} \mathrm{I}-\mathrm{DBP}$ and ${ }^{125} \mathrm{I}-\mathrm{G}$-actin were collected and aliquots were counted in a gamma counter to determine the elution of DBP and $\mathrm{G}$-actin. Specific activities for DBP of $0.5-4.0 \mu \mathrm{Ci} / \mu \mathrm{g}$ were achieved. The specific activity of $\mathrm{G}$-actin was $0.04 \mu \mathrm{Ci} / \mu \mathrm{g}$.

$50 \mu \mathrm{g}$ of RSA were labeled with ${ }^{131} \mathrm{I}$ by the lactoperoxidase technique and purified on a calibrated, $1 \times 60 \mathrm{~cm}$ column of AcA-44 at $4^{\circ} \mathrm{C}$. Specific activities of $5-30 \mu \mathrm{Ci} / \mu \mathrm{g}$ were achieved. 
All radiolabeled proteins were used within $24 \mathrm{~h}$ of their preparation. Preparation of holo (G-actin)-DBP complex. ${ }^{125} \mathrm{I}$-DBP-actin complex was prepared by incubating purified, radiolabeled DBP with unlabeled G-actin in PBS in an equimolar ratio at $0^{\circ} \mathrm{C}$ for a minimum of $30 \mathrm{~min}$.

Animal experiments. Male Sprague-Dawley rats weighing 196-500 $\mathrm{g}$ were used. At least $48 \mathrm{~h}$ before experimentation, $0.01 \% \mathrm{KI}$ was added to their drinking water. Animals were anesthetized in an ether chamber and were injected intravenously (via a tail vein using a $1 \mathrm{~cm}^{3}$ insulin syringe with a 27 -gauge needle) with 5-10 $\mu$ g of either ${ }^{125} \mathrm{I}$-DBP or ${ }^{125} \mathrm{I}$ DBP-actin complex (0.46-1.2 $\mu \mathrm{Ci})$.

To provide in vivo evidence of the purity of our DBP, $80 \mu \mathrm{g}$ of DBP were radiolabeled as above with $0.6 \mathrm{mCi}$ of ${ }^{125} \mathrm{I}$. One rat received 152 $\mu \mathrm{Ci}$ of this ${ }^{125} \mathrm{I}$-DBP. After $45 \mathrm{~min}$, this screening rat was bled via cardiac puncture and the plasma was separated. A second rat then received 1.5 $\mu \mathrm{Ci}(370 \mu \mathrm{l})$ of the screening rat's plasma. This rat was then studied for the disposition of the screened ${ }^{125}$ I-DBP.

In separate experiments, rats were injected with $\mathbf{4 0} \mu \mathrm{g}$ of labeled Gactin $(1.6 \mu \mathrm{Ci})$ or with both ${ }^{131}$ I-RSA and ${ }^{125}$ I-DBP. 10 rats each were injected with ${ }^{125} \mathrm{I}$-DBP or ${ }^{125} \mathrm{I}-\mathrm{DBP}$-actin complex. Five rats were injected with labeled monomeric actin, and four rats received ${ }^{131}$ I-RSA and ${ }^{125}$ IDBP simultaneously. One rat received the screening rat's ${ }^{125}$ I-DBP plasma. Hematocrits were determined in all animals pre- and postexperimentation.

Blood radioactivity. $2 \mathrm{~min}$ after injection, $200 \mu \mathrm{l}$ of blood were obtained by cardiac puncture using a syringe with a 27 -gauge needle. Blood was transferred to $1 \mathrm{~cm}^{3}$ Eppendorf centrifuge tubes containing $10 \mu \mathrm{l}$ $(10 \mathrm{U})$ of heparin. The plasma was separated by centrifugation for 2.5 min at $12,000 \mathrm{~g}$ at $20^{\circ} \mathrm{C}$. Total plasma and cold, $20 \%$ TCA-precipitable radioactivity were determined on 20- $\mu$ l aliquots of the plasma samples in the gamma counter (Micromedic 4/600, Micromedic Systems, Horsham, PA).

Serial blood samples were obtained, and their radioactivity was expressed as the percentage of that in the 2-min sample.

Immunoprecipitation. Antiserum to rat DBP was raised in rabbits and the antibody purified on a protein A-Sepharose 4B column. The final dilution of the antibody after purification was $1: 3$, and this antibody displayed recognition of DBP and the DBP-actin complex. The optimal amount of antibody required to precipitate all the DBP was determined by mixing serial dilutions $(200 \mu \mathrm{l})$ with $10-\mu \mathrm{l}$ samples of rat plasma after the addition of 25 -hydroxy- $\left[{ }^{3} \mathrm{H}\right]$ vitamin $\mathrm{D}_{3}(10,000 \mathrm{dpm})$. After an overnight incubation at $4^{\circ} \mathrm{C}, 10 \mu \mathrm{l}$ of IgGsorb (IgG binding capacity, 1.18 $\mathrm{mg} \mathrm{IgG/ml)} \mathrm{were} \mathrm{added} \mathrm{with} \mathrm{gentle} \mathrm{shaking} \mathrm{for} 20 \mathrm{~min}$. These samples were centrifuged at $1,000 \mathrm{rpm}$ for $20 \mathrm{~min}$. The radioactivities in the supernatant and pellet were determined in the liquid scintillation counter (Packard Tri-Carb, Packard Instruments Co., Inc., Downers Grove, IL).

Plasma samples $(10 \mu \mathrm{l})$ from two rats who received ${ }^{125} \mathrm{I}-\mathrm{G}$-actin were handled as above using $200 \mu \mathrm{l}$ of a 1:3 dilution of the antibody. Immunoprecipitable radioactivity, representing that bound to DBP, was determined by gamma spectrophotometry.

Tissue appearance of radioactivity. $2 \mathrm{~h}$ after the administration of ${ }^{125} \mathrm{I}$-DBP or ${ }^{125} \mathrm{I}-\mathrm{DBP}$-actin complex, the animals were anesthetized with ether and a longitudinal middle abdominal and chest incision was made to the viscera. A heparin containing catheter was placed within the left ventricle, and the plasma was obtained and separated as previously described. The right femoral vein was then severed and the animals were perfused with ice-cold PBS via the cardiac catheter. The perfusion was continued until the organs were blanched (20-30 min). Small organs were harvested into plastic scintillation vials and their radioactivity determined in a Packard 3001 gamma spectrophotometer. The entire liver and a portion of the liver and skeletal muscle from the anterior thigh opposite the severed femoral vein were weighed. Radioactivity was determined on the weighed portions of the liver and skeletal muscle.

Dual tracer studies. In a separate set of experiments, rats were injected with both ${ }^{125}$ I-DBP and ${ }^{131} \mathrm{I}-\mathrm{RSA}$. Without perfusion, rats were sacrificed and the organs harvested at regular intervals after injection, and plasma and tissue ratios of ${ }^{125} \mathrm{I} /{ }^{131} \mathrm{I}$ were determined by double channel gamma spectrophotometry.

For urine and stool collections, each rat was housed in a metabolic cage and all urine and stool was collected separately. The first 24-h urine was collected on ice.

Plasma samples and samples from the first 24-h urine collections were analyzed by gel electrophoresis using $10 \%$ polyacrylamide separating gel as previously described (23). 3-mm gel segments were sliced and assayed for radioactivity.

Sucrose gradient ultracentrifugation. Linear $4.8 \mathrm{ml}, 5-20 \%$ (wt/vol) sucrose density gradients were prepared in either PBS with the addition of $0.02 \%$ (wt/vol) $\mathrm{NaN}_{3}\left({ }^{125} \mathrm{I}\right.$-DBP or ${ }^{125} \mathrm{I}$-DBP-actin complex) or in buffer A ( ${ }^{125}$ I-G-actin). Gradients were also prepared in buffer $A$ with the addition of $1 \mathrm{mM} \mathrm{CaCl}$ or buffer $A$ with the addition of $0.1 \mathrm{mM} \mathrm{Ca}$ EDTA ( $\left.{ }^{125} \mathrm{I}-\mathrm{G}-\mathrm{actin}\right)$. Injected materials and plasma samples were layered onto the tops of these gradients and centrifuged at $42,000 \mathrm{rpm}$ in an SW 50.1 rotor for $18 \mathrm{~h}$ at $4^{\circ} \mathrm{C}$ in an ultracentrifuge (Beckman L5-50B, Beckman Instruments, Inc., Fullerton, CA). Fractions were collected and their radioactivity was determined. BSA was used as a standard and was measured by its ultraviolet absorbance at $280 \mathrm{~nm}$.

Single radial immunodiffusion. Slides were prepared for single radial immunodiffusion assay of rat DBP, using $1 \%$ agarose in tris buffered saline ( $0.01 \mathrm{M}$ tris, $0.15 \mathrm{M} \mathrm{NaCl}, \mathrm{pH}$ 7.2) containing rabbit anti-rat DBP antiserum as previously described (24-26). Standards on each slide were rat serum DBP of known concentration. The concentration of DBP in the plasma of the experimental animals was determined from the standard curve.

Other methods. The half-times $\left(t_{1 / 2}\right)$ of the DBP and DBP-actin disappearance curves were calculated by determining the slopes of each experiment at $50 \%$ and determining the average of all rats. The disappearance data were analyzed statistically in a two-stage multiple regression analysis (27). In the first regression the dosage was used as the dependent variable and regressed with time and animal irrespective of treatment (DBP-actin) or nontreatment (DBP). The residuals from this regression were then regressed with treatment or nontreatment as the independent variables. The significance of nontreatment versus treatment was analyzed by the Student's $t$ test.

In the tissue accumulation analysis, total plasma radioactivity was determined for each rat by correcting the 30- $\mu$ aliquot for the total plasma volume (28). Total skeletal muscle weight was assumed to be $45.4 \%$ of the mature rat's total body weight (29).

\section{Results}

Animal features during experimentation. To ascertain that tracer amounts of DBP were used and to assess the effects of experimentation on blood volume, pre and post hematocrits were done and showed a modest lowering of hematocrit (3-10\%). Plasma DBP concentration, by radial immunodiffusion assay, declined $<13 \%$, when pre- and postinjection samples were compared.

Properties of radiolabeled proteins. Labeled rat DBP, G-actin and RSA eluted as single symmetrical peaks from the AcA-44 columns. Additional analyses by sucrose density gradient ultracentrifugation and PAGE confirmed the homogeneity of these proteins. The radiolabeled actin was shown to co-polymerize with the native G-actin used at critical concentration.

Plasma clearance of ${ }^{125} I-D B P$ and ${ }^{131} I-R S A$. Fig. 1 shows the plasma disappearance curves of TCA-precipitable radioactivity after the simultaneous intravenous administration of ${ }^{125} \mathrm{I}$ DBP and ${ }^{131} \mathrm{I}-\mathrm{RSA}$. In all instances, the TCA-precipitable radioactivity was $>88 \%$ of total plasma radioactivity. Two slopes were seen for each protein. The initial slope of the DBP curve revealed a $t_{1 / 2}$ of $2.6 \mathrm{~h}$, while that of RSA was $3.0 \mathrm{~h}$. The second, slower, slopes corresponded to $\mathrm{t}_{1 / 2}$ of $7.0 \mathrm{~h}$ for the DBP and $21.0 \mathrm{~h}$ for the RSA.

Tissues ratios of ${ }^{125} I-D B P$ and ${ }^{131} I-R S A$. After the simultaneous administration of ${ }^{125} \mathrm{I}-\mathrm{DBP}$ and ${ }^{131} \mathrm{I}$-RSA, most of the tissues examined contained more ${ }^{125} I$ than ${ }^{131} I$ (Fig. 2), consistent 


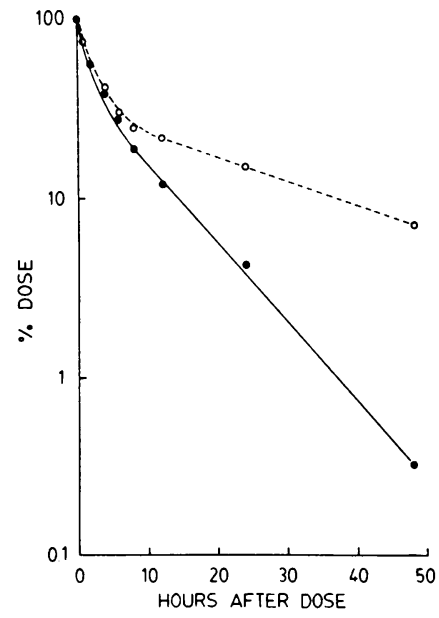

Figure 1. Plasma disappearance of TCA-precipitable radioactivity after the simultaneous intravenous administration of ${ }^{125} \mathrm{I}$ DBP and ${ }^{131}$ I-RSA to the rat. Rats were injected with tracer amounts of ${ }^{125} \mathrm{I}-\mathrm{DBP}(-\bullet-)$ and ${ }^{131}$ I-RSA (--O--). Serial cardiac blood samples were obtained over a 48-h period and the TCA-precipitable radioactivity of plasma was determined. Data are expressed as a percentage of the 2 -min value.

with the more rapid plasma egress of ${ }^{125}$ I-DBP (Fig. 1). At early time points, liver, proximal gut, kidney, and skeletal muscle contained more ${ }^{125} \mathrm{I}$, with increasing amounts observed in kidney and skeletal muscle over 4-8 h after injection. Relatively smaller accumulations favoring ${ }^{125} \mathrm{I}$ were seen in bone, brain, and lung.

Urine and stool radioactivity. Both isotopes $\left({ }^{125} \mathrm{I},{ }^{131} \mathrm{I}\right)$ appeared in the urine and stool (Table I). ${ }^{125} \mathrm{I}$ was excreted more rapidly into urine. At $24 \mathrm{~h} \sim 43 \%$ of the ${ }^{125}$ I and $21 \%$ of the ${ }^{131} \mathrm{I}$ doses appeared in the urine. By $48 \mathrm{~h}$, over half of the ${ }^{125} \mathrm{I}$ dose, and $33 \%$ of the ${ }^{131} I$ dose were in the urine. In contrast, relatively small amounts of either isotope were found in the 48h stool collections.

Plasma disappearance of ${ }^{125} I-D B P, D B P$-actin complex and ${ }^{125} \mathrm{I}$-G-actin. Fig. $3 \mathrm{~A}$ depicts the plasma disappearances of TCAprecipitable radioactivity after the injection of ${ }^{125} \mathrm{I}$-apo-DBP, the ${ }^{125}$ I-DBP-actin complex, or the ${ }^{125} \mathrm{I}-\mathrm{DBP}$ previously screened in another rat. Though not depicted in Fig. 3, the 24-h \% of dose as TCA-precipitable radioactivity was $6.2 \pm 3.4$ for DBP, $4.65 \pm 3.4$ for DBP-actin, and 5.0 for ${ }^{125}$ I-screened DBP. These values were clearly different from the same time points for albumin (Fig. 1). In all instances, the TCA-precipitable radioactivity was $>85 \%$ of total radioactivity. The curves are nearly identical, with a $t_{1 / 2}$ of $2.6 \mathrm{~h}$. Fig. $3 \mathrm{~B}$ shows the plasma clearances of injected ${ }^{125} \mathrm{I}$ -

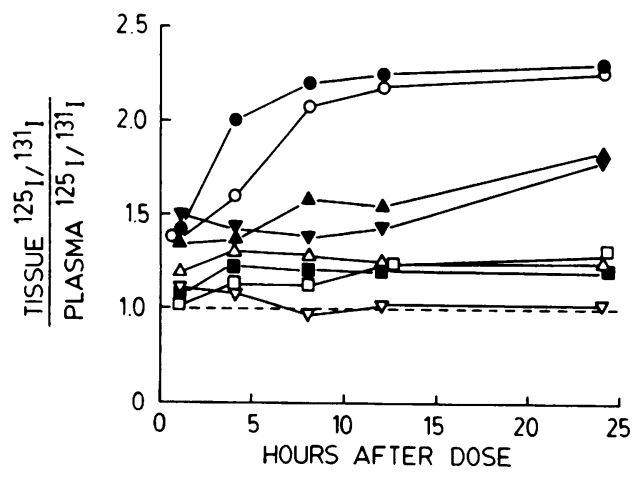

Figure 2. Tissue to plasma ratios of ${ }^{125}$ I-DBP and ${ }^{131}$ I-RSA radioactivity after their simultaneous intravenous administration to the rat. Rats were simultaneously injected with ${ }^{125} \mathrm{I}-\mathrm{DBP}$ and ${ }^{131} \mathrm{I}$-RSA. At regular intervals after administration, the animals were killed and the organs obtained. The ratios of ${ }^{125} \mathrm{I} /{ }^{131} \mathrm{I}$ for the various organs were obtained by double channel gamma spectrophotometry. $\bullet$, kidney; $\bigcirc$, skeletal muscle; $\Delta$, proximal gut; $\nabla$, liver; $\square$, bone; $\Delta$, brain; $\bullet$, lung; $\nabla$, heart.
Table I. Appearance of Radioactivity in Urine and Stool of Rats after Intravenous Administration of ${ }^{125} I-D B P$ and ${ }^{131} I-R S A$

\begin{tabular}{ccc}
\hline Source & ${ }^{125} \mathrm{I}-\mathrm{DBP}(\%$ of dose)* & ${ }^{131}{ }^{*}$-RSA $(\% \text { of dose })^{*}$ \\
\hline Urine & & \\
$24 \mathrm{~h}$ & $42.7 \pm 8.7$ & $21.4 \pm 5.9$ \\
$48 \mathrm{~h}$ & $13.8 \pm 8.6$ & $11.9 \pm 3.7$ \\
Stool & & \\
$48 \mathrm{~h}$ & $5.7 \pm 0.8$ & $3.7 \pm 1.3$ \\
\hline
\end{tabular}

* Expressed as the mean percentage of dose \pm SEM.

$n=3$ or 4 rats in each group.

G-actin and ${ }^{125} \mathrm{I}$-apo-DBP. The $24-\mathrm{h}$ value for ${ }^{125} \mathrm{I}-\mathrm{G}$-actin was $4.0 \pm 4.0 \%$. These plasma clearances were almost identical.

Table II shows the percentages of plasma radioactivity that were precipitable with $20 \%$ TCA and by immunoprecipitation with monospecific antibody to DBP in rats receiving ${ }^{125} \mathrm{I}-\mathrm{G}$-actin. Both analyses yielded very similar results.

Based on the stable hematocrits and serum DBP concentration $(414 \mu \mathrm{g} / \mathrm{ml}$ by radial immunodiffusion) throughout the experimental periods, the production rate was able to be calculated using the formula, $C=C_{0} \mathrm{e}^{-k t}$, where $C$ is the concentration of radiolabeled protein at any time, $C_{0}$ is the concentration of radiolabeled protein at time zero, $\mathrm{t}$ is time and $k$ is the fractional catabolic rate constant (30). Although the initial rapid curve most likely represents mixing of the DBP with its intra- and extravascular pool and the second, slower part of the curve rep-
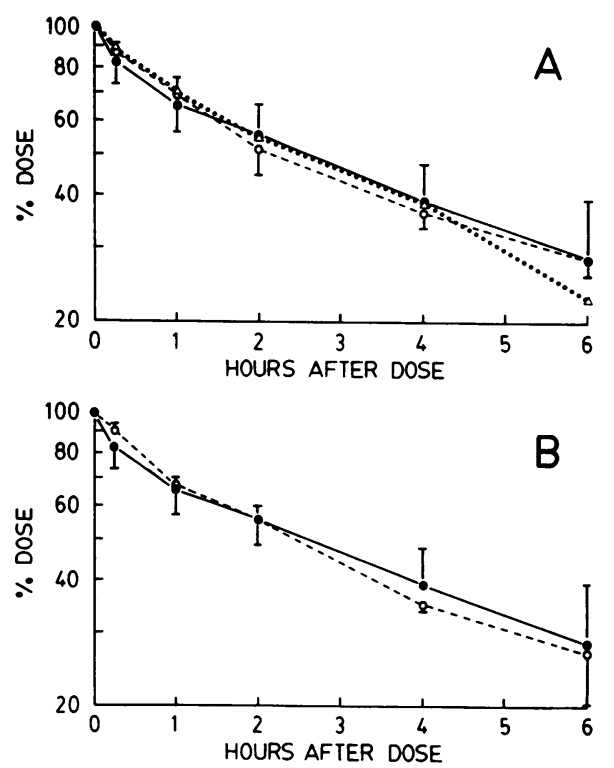

Figure 3. Plasma disappearance of TCA-precipitable radioactivity after intravenous administration of ${ }^{125} \mathrm{I}$-DBP, ${ }^{125} \mathrm{I}$-screened DBP, ${ }^{125} \mathrm{I}$-DBPactin complex, or ${ }^{125} \mathrm{I}-\mathrm{G}$-actin to the rat. $(A) 5-7 \mu \mathrm{g}$ of ${ }^{125} \mathrm{I}$-DBP $(-\bullet-)$ or ${ }^{125} \mathrm{I}$-DBP-actin complex (-- $\left.\mathrm{O}--\right)^{-}$, or ${ }^{125} \mathrm{I}$-screened DBP $(\cdots \Delta \cdots)$ were administered intravenously to rats. Serial cardiac blood samples were obtained and the TCA-precipitable radioactivity of plasma was determined. Data are expressed as a percentage of the 2-min value. $(B){ }^{125} \mathrm{I}-\mathrm{G}$-actin $(40 \mu \mathrm{g})(--\mathrm{O}--)$ were injected intravenously into rats and the plasma was separated from serial cardiac blood samples. Plasma TCA-precipitable radioactivity was determined and expressed as a percentage of the 2-min sample. This curve was indistinguishable from that seen after apo-DBP $(-\bullet-)$ injection. 
Table II. Percentages of TCA and

Immunoprecipitable Radioactivity after the Intravenous Injection of ${ }^{125} I-G$-Actin to Rats

\begin{tabular}{lll}
\hline Time (h) & TCA & IP* \\
\hline & $\%$ & $\%$ \\
$0.00(2 \mathrm{~min})$ & 97.0 & 95.0 \\
0.25 & 98.3 & 95.7 \\
1.00 & 92.0 & 91.7 \\
2.00 & 92.1 & 95.1 \\
4.00 & 95.3 & 90.7 \\
6.00 & 92.8 & 87.8 \\
24.00 & 88.1 & 80.0 \\
\hline
\end{tabular}

* IP, immunoprecipitable.

resents the rate of degradation, production rates were calculated based on both $t_{1 / 2}$ values. Using the faster slope with $t_{1 / 2}$ of 2.6 $\mathrm{h}$, the production rate was $5.7 \mathrm{mg} / \mathrm{kg}$ per $\mathrm{h}$. The rate using the second, slower half time of $7 \mathrm{~h}$ was $2.1 \mathrm{mg} / \mathrm{kg}$ per $\mathrm{h}$.

Tissue accumulation of ${ }^{125} I-D B P$ or ${ }^{125} I-D B P$-actin complex radioactivity in saline perfused organs. After the administration of either ${ }^{125} \mathrm{I}$-DBP or ${ }^{125} \mathrm{I}$-DBP-actin complex the organ distribution of radioactivity, after perfusion with saline, revealed the greatest accumulations in skeletal muscle, liver, and kidney (Table III). The radioactive accumulations in organs from rats receiving DBP were not statistically different from the DBP-actin organs $(P=0.4$ for skeletal muscle; $P=0.3$ for liver; $P=0.35$ for kidney).

Properties of radiolabeled materials in plasma and urine. Electrophoresis of rat plasma obtained at $6 \mathrm{~h}$ after the injection of ${ }^{125} \mathrm{I}-\mathrm{DBP}$ by $10 \%$ PAGE revealed most of the radioactive material to be intact DBP (Fig. $4 A$ ). In contrast, urine from the first 24 hour collection revealed small-sized material with a net negative charge running at the dye front, suggesting the presence of iodine and iodopeptides (Fig. $4 \mathrm{~B}$ ).

Table III. Tissue Distribution of ${ }^{125}$ I Radioactivity

$2 h$ after the Intravenous Injection of

${ }^{125}$ I-DBP or ${ }^{125}$ I-DBP-Actin Complex to the Rat

\begin{tabular}{lcc}
\hline Organ & DBP & DBP-Actin \\
\hline & \% dose/organ* & \% dose/organ* \\
& $27.36 \pm 8.38$ & $28.78 \pm 14.80$ \\
Plasma $^{*}$ & $3.87 \pm 1.67$ & $4.48 \pm 2.20$ \\
Skeletal muscle $^{8}$ & $1.64 \pm 0.13$ & $2.40 \pm 1.10$ \\
Liver & $1.39 \pm 0.76$ & $0.87 \pm 0.39$ \\
Kidney & $0.50 \pm 0.34$ & $0.73 \pm 0.36$ \\
Small intestine & $0.34 \pm 0.34$ & $0.39 \pm 0.27$ \\
Testes & $0.19 \pm 0.19$ & $0.40 \pm 0.01$ \\
Lung & $0.13 \pm 0.07$ & $0.13 \pm 0.07$ \\
Spleen & $0.10 \pm 0.07$ & $0.14 \pm 0.10$ \\
Heart & $0.04 \pm 0.02$ & $0.02 \pm 0.01$ \\
Tibia & $0.02 \pm 0.006$ & $0.04 \pm 0.04$ \\
Brain & & \\
\hline
\end{tabular}

$* \% \pm \mathrm{SEM}$

"Assumes plasma volume $=40.4 \mathrm{ml} / \mathrm{kg}$.

${ }^{8}$ Assumes skeletal muscle constitutes $45.4 \%$ total body weight.

$n=3-5$ rats in each group.

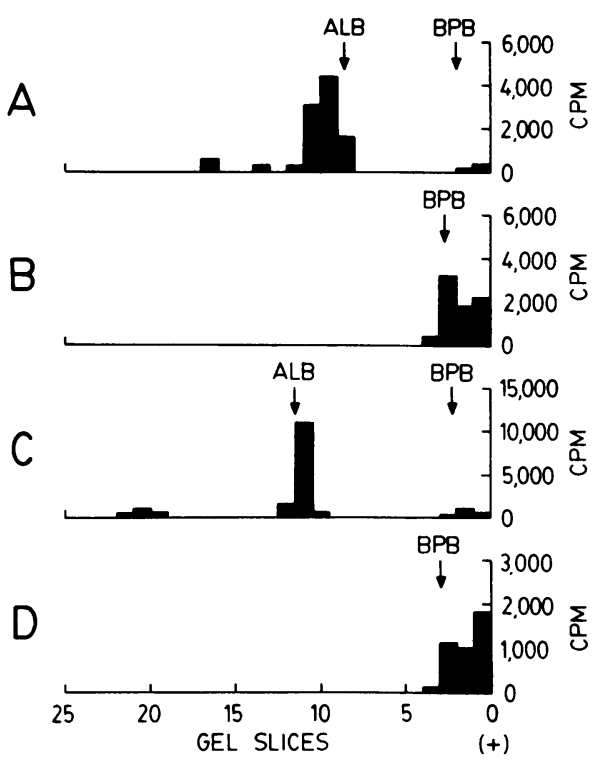

Figure 4. 10\% PAGE of plasma and urine radioactivity after the intravenous administration of ${ }^{125} \mathrm{I}-\mathrm{DBP}$ and ${ }^{131} \mathrm{I}-\mathrm{RSA}$ to the rat. $(A) 6 \mathrm{~h}$ plasma samples after intravenous administration of ${ }^{125} \mathrm{I}-\mathrm{DBP}$ to the rat were analyzed by $10 \%$ PAGE. BPB, Bromophenol Blue tracking dye front; ALB, albumin; (+), anode. Samples were electrophoresed on $10 \%$ polyacrylamide separating gel, $7.5 \mathrm{~cm}$ length. The gel was sliced into 3-mm segments and analyzed by gamma counting for ${ }^{125} \mathrm{I}$ content. $(B)$ Represents a sample of urine from the first 24-h urine collection. It was handled as in $(A)$. $(C)$ Represents the 6-h plasma sample after intravenous administration of ${ }^{131}$ I-RSA and analyzed as in $(A)$ for ${ }^{131}$ I content. $(D)$ Representative sample from the first 24-h urine collection of rats injected with ${ }^{131}$ I-RSA.

PAGE analysis of plasma from ${ }^{131} \mathrm{I}$-albumin injected rats showed the larger molecular weight material to be intact albumin (Fig. $4 C$ ). Urine analysis revealed small sized, negatively charged particles near the gel front, as in the case of ${ }^{125} \mathrm{I}-\mathrm{DBP}$. Of the ${ }^{131} \mathrm{I}$ and ${ }^{125} \mathrm{I}$ in the urine, no intact proteins were detected.

Sucrose density ultracentrifugation. The sedimentation profiles of injected materials and plasma samples are shown in Fig. 5. The plasma samples of ${ }^{125} \mathrm{I}-\mathrm{DBP}$ and DBP-actin complex treated rats (Fig. $5 C$ ) had sedimentation profiles similar to the injected materials (Fig. $5 \mathrm{~A}$ ) with apo-DBP sedimenting more slowly than the actin-DBP complex. The monomeric actin injected (Fig. $5 B$ ) revealed a sedimentation slower than BSA. However, representative plasma samples, (Fig. $5 \mathrm{D}$ ), from rats receiving ${ }^{125} \mathrm{I}-\mathrm{G}$-actin sedimented at $5-6 \mathrm{~S}$, as did the actin-DBP complex. No aggregation, degradation nor free monomeric actin was detected. In addition, no faster sedimenting compounds suggesting the binding of actin to gelsolin were seen when the ${ }^{125} \mathrm{I}-\mathrm{G}$-actin plasma samples were run on gradients made in 1 $\mathrm{mM} \mathrm{CaCl}{ }_{2}$.

\section{Discussion}

The present data indicate that DBP is cleared from the rat circulation faster than rat serum albumin. In addition, the accumulation of DBP radioactivity in rat tissues was faster than albumin accumulations (Figs. 1 and 2). As observed in rabbits (8), no intermediate sized or DBP fragment was observed in rat blood, suggesting the action of multiple proteases in the degradation of DBP. In support of these findings in blood were the 


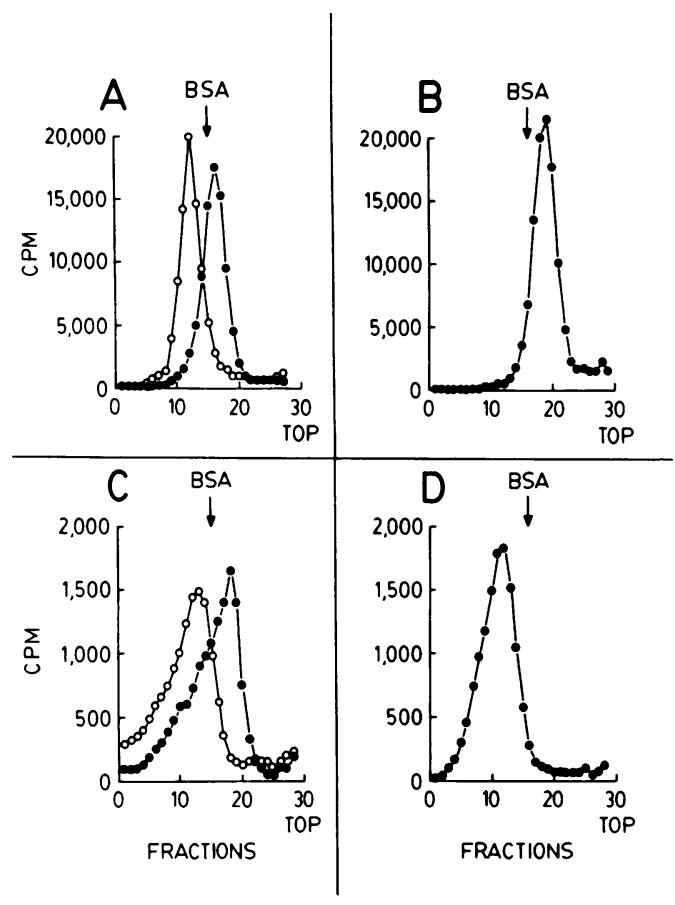

Figure 5. Sucrose gradient ultracentrifugation of injected samples and plasma samples following intravenous administration of ${ }^{125} \mathrm{I}-\mathrm{DBP}$ or

${ }^{125} \mathrm{I}$-DBP-actin complex or ${ }^{125} \mathrm{I}-\mathrm{G}$-actin to the rat. $(A) 5-20 \%$ linear sucrose gradients were prepared in PBS $8 \mathrm{~h}$ before layering and stored at $4^{\circ} \mathrm{C}$. $50 \mu \mathrm{l}$ of the injected ${ }^{125} \mathrm{I}$-DBP $(-\bullet-)$ or ${ }^{125} \mathrm{I}$-DBP-actin $(-0-)$ were layered, and the gradients were centrifuged $18 \mathrm{~h}$ at $42,000 \mathrm{rpm}$. Fractions, via bottom punctures, were collected and analyzed for their ${ }^{125}$ I content. $(B)$ Gradients were prepared as in $(A)$ except that buffer $A$ was used. The G-actin injectate was layered onto the tops and otherwise handled as in $(A)$. $(C)$ Representative plasma samples from rats $2 \mathrm{~h}$ after receiving ${ }^{125}$ I-DBP $(-\bullet-)$ or ${ }^{125} \mathrm{I}$-DBPactin $(-\circ-)$ were handled as in $(A)$. (D) Representative plasma sample from a rat $2 \mathrm{~h}$ after receiving ${ }^{125} \mathrm{I}$-G-actin was handled as in $(B)$.

observations that urine DBP radioactivity was exclusively small sized, negatively charged material (Fig. 4).

As with all purification and protein-modification schemes, one must be concerned that the products studied behaved as would the native proteins. In addition to their identical physiochemical features to the reference proteins, functional similarities were sought. Labeled G-actin was shown to polymerize along with carrier G-actin to F-actin. ${ }^{125} \mathrm{I}-\mathrm{DBP}$ was shown to bind mole per mole with G-actin. Finally, no differences were found in the plasma disappearance kinetics when using either ${ }^{125} \mathrm{I}-\mathrm{DBP}$ previously screened in one rat or ${ }^{125}$ I-DBP purified on the AcA 44 column (Fig. 3). Unlike earlier observations (2), rat DBP exhibited no tendency to aggregate during our experimental procedures.

Since the ratio of plasma DBP to its sterol ligands is so high, several observers have suspected functions for this protein beyond the storage, solubility and transport of vitamin D sterols $(13,14,31)$. Studies have revealed a high affinity, specific binding of DBP to G-actin $(15,23)$. How might a function be carried out between an extracellular protein and a major cytoskeletal constituent? Recent studies have suggested an intimate association of DBP with the plasma membranes of immunocytes and cytotrophoblasts (32-34). Whether derived from the plasma DBP pool or synthesized by nonhepatic cells, cell-associated DBP might serve as a linkage from the cell membrane to the cyto- skeleton, but further studies are needed to support such a hypothesis (35). Alternatively, cellular actin liberated during cell lysis may require a scavenger system for its clearance from extracellular fluid.

Lind et al. recently found that actin accelerated the clearance of plasma gelsolin and DBP in rabbits (36). These authors injected F-actin, but did not study the kinetics of G-actin directly to determine what role, if any, gelsolin played in the disposition of monomeric actin. Only TCA-precipitable radioactivity was determined in their analyses, and the integrity of the labeled proteins was not verified. It is possible, however, that there are species differences in the disposition of the DBP-actin complex.

Our results clearly show DBP to be the major plasma component in vivo for the disposition of G-actin (Figs. 3, 5, and Table II). Virtually all of the injected G-actin in plasma was associated with DBP as evidenced by our immunoprecipitation data with monospecific anti-rat DBP, and no aggregates or actin fragments were detected. The sucrose gradient analysis in $1 \mathrm{mM}$ $\mathrm{CaCl}_{2}$, which should favor the continued binding of gelsolin to actin if it had occurred in vivo, failed to show complexes that sedimented faster than the DBP-actin complex. The clearances of DBP, G-actin, and the DBP-actin complex from plasma were nearly identical. These findings suggest a constitutive role for DBP in the disposition and survivorship of plasma G-actin. Our studies examined the fate of a relatively small amount of actin, since the plasma DBP capacity to bind actin (as estimated from plasma DBP concentration and binding studies) is in the order of $500-600 \mu \mathrm{g} / \mathrm{ml}$ plasma.

One can presume that the introduction of critical concentrations of actin (15) into the isotonic milieu of plasma would result in its polymerization and disastrous hemodynamic consequences were it not for a mechanism to prevent F-actin formation. Our present results clearly indicate DBP to be a major component in the extracellular handling of G-actin. Others have identified a possible role for gelsolin in the plasma binding and disposition of F-actin $(31,36)$. Since this protein severs F-actin, its action along with the monomer sequestration provided by DBP may provide a dual mechanism to protect the organism from cell-liberated actin moieties. The precise nature of actin liberated during cytolysis is not known, however, and a plethora of intracellular actin binding proteins are likely to be released during this process (37). Some in vivo evidence for the presence of plasma DBP-actin complexes is provided by observations in plasma from pregnant women (38) and patients with hepatic necrosis (39).

Additional work, at various actin concentrations or conditions leading to in vivo tissue injury and cell lysis, are necessary to further characterize the in vivo mechanism for extracellular actin disposal. Our results, however, appear to indicate a major involvement of DBP in such a mechanism.

\section{Acknowledgments}

We are grateful to Dr. Henry Glick, Department of Epidemiology, University of Pennsylvania, Philadelphia, PA for assistance in performing the statistical analyses of our data; Dr. David R. Fraser and D. E. M. Lawson for helpful discussions and assistance.

This work was supported by the National Institutes of Health grants 1 T32 AM-07481 and AM-28292.

\section{References}

1. Imawari, M., K. Kida, and D. S. Goodman. 1976. The transport of vitamin $\mathrm{D}$ and its 25 -hydroxymetabolite in human plasma. Isolation 
and partial characterization of vitamin D and 25-hydroxyvitamin D binding protein. J. Clin. Invest. 58:514-523.

2. Bouillon, R., H. Van Baelen, W. Rombauts, and P. DeMoor. 1978. The isolation and characterization of the vitamin D-binding protein from rat serum. J. Biol. Chem. 253:4426-4431.

3. Haddad, J. G., and J. Walgate. 1976. 25-hydroxyvitamin D transport in human plasma. Isolation and partial characterization of calcifidiol binding protein. J. Biol. Chem. 251:4803-4809.

4. Haddad, J. G., L. Hillman, and S. Rojanasathit. 1976. Human serum binding capacity for 25-hydroxyergocalciferol and 25-hydroxycholecalciferol. J. Clin. Endocrinol. \& Metab. 43:86-91.

5. Prunier, J. H., A. G. Bearn, and H. Cleve. 1964. Site of formation of the group specific protein and certain other serum proteins. Proc. Soc. Exp. Biol. Med. 115:1005-1007.

6. Haddad, J. G., and J. Walgate. 1976. Radioimmunoassay of the binding protein for vitamin $\mathrm{D}$ and its metabolites in human serum. Concentrations in normal subjects and patients with disorders of mineral homeostasis. J. Clin. Invest. 58:1217-1277.

7. Cleve, H. 1973. The variants of the group specific component. Isr. J. Med. Sci. 9:1133-1146.

8. Haddad, J. G., D. R. Fraser, and D. E. M. Lawson. 1981. Vitamin$\mathrm{D}$ binding protein. Turnover and fate in the rabbit. J. Clin. Invest. 67: 1550-1560.

9. Kawakami, M., C. B. Blum, R. Ramakrishnan, R. B. Dell, and D. W. S. Goodman. 1981. Turnover of the plasma binding protein for vitamin D and its metabolites in normal human subjects. J. Clin. Endocrinol. \& Metab. 53:1110-1116.

10. Rojanasathit, S., and J. G. Haddad. 1977. Ontogeny and effect of vitamin $\mathrm{D}$ deprivation on rat serum 25-hydroxyvitamin D-binding proteins. Endocrinology. 100:642-647.

11. Imawari, M., and D. W. S. Goodman. 1977. Immunological and immunoassay studies of the binding protein for vitamin $\mathrm{D}$ and its metabolites in human serum. J. Clin. Invest. 59:432-442.

12. Bouillon, R., H. VanBaelen, and P. DeMoor. 1977. The measurements of the vitamin D-binding protein in human serum. J. Clin. Endocrinol. \& Metab. 45:225-231.

13. Haddad, J. G. 1982. Human binding protein for vitamin D and its metabolites (DBP). Evidence that actin is the DBP component in human skeletal muscle. Arch. Biochem. Biophys. 213:538-544.

14. Van Baelen, H., R. Bouillon, and P. DeMoor. 1980. Vitamin Dbinding protein (Gc-globulin) binds actin. J. Biol. Chem. 255:2270-2272.

15. Lees, A., J. G. Haddad, and S. Lin. 1984. Brevin and the vitamin D-binding protein: Comparison of the effects of two serum binding proteins on actin assembly and disassembly. Biochemistry. 23:3038-3047.

16. Thorstensson, R., G. Utter, and G. Norberg. 1982. Further characterization of the $\mathrm{Ca}^{2+}$-dependent $\mathrm{F}$-actin depolymerizing protein of human serum. Eur. J. Biochem. 126:11-16.

17. Norberg, G., R. Thorstensson, G. Utter, and A. Fagralus. 1979. F-actin depolymerizing activity of human serum. Eur. J. Biochem. 100: 575-583.

18. Janmey, P. A., S. E. Lind, H. L. Yen, and T. P. Stossel. 1985. Effects of semi-dilute actin solutions on the mobility of fibrin protofibrils during clot formation. Biochim. Biophys. Acta. 841:151-158.

19. Haddad, J. G., M. A. Kowalski, and J. W. Sanger. 1984. Actin affinity chromatography in the purification of human, avian and other mammalian plasma proteins binding vitamin $\mathrm{D}$ and its metabolites. ( $\mathrm{Gc}$ globulins.) Biochem. J. 218:805-810.

20. Lowry, O. H., N. J. Rosebrough, A. L. Farr, and R. J. Randall. 1951. Protein measurement with the Folin phenol reagent. J. Biol. Chem. 193:265-275.
21. Spudich, J. A., and S. Watt. 1971. The regulation of rabbit skeletal muscle contraction. J. Biol. Chem. 246:4866-4871.

22. Myachi, Y., J. L. Vattukaitus, E. Nieschlug, and M. B. Lipsett. 1982. Enzymatic radioiodination of gonadotropins. J. Clin. Endocrinol. \& Metab. 34:23-28.

23. Cooke, N. C., J. Walgate, and J. G. Haddad. 1979. Human serum binding protein for vitamin $\mathrm{D}$ and its metabolites. Specific high affinity association with a protein in nucleated tissue. J. Biol. Chem. 254:59655971.

24. Mancini, G., A. O. Carbonara, and J. F. Heremans. 1965. Immunochemical quantitation of antigens by single radial immunodiffusion. Immunochemistry. 2:235-254.

25. Van Baelen, H., and P. DeMoor. 1974. Immunochemical quantitation of human transcortin. J. Clin. Endocrinol. \& Metab. 39:160163.

26. Haddad, J. G., J. Abrams, and J. Walgate. 1981. Affinity chromatography with 25-hydroxycholecalciferol ester in the isolation of the binding protein for vitamin $\mathrm{D}$ and its metabolites from human serum. Metab. Bone Dis. Rel. Res. 3:43-46.

27. Pedhazur, E. J. 1982. Multiple Categorical Variables and Factorial Designs. In Multiple Regression in Behavioral Research. Second ed. Holt, Rinehart, Winston, New York. 334-393.

28. Baker, H. J., R. J. Lindsay, and S. H. Weisbroth. 1980. Appendix I, Selected normative data. In The Laboratory Rat Volume II. Academic Press, Inc., New York.

29. Donaldson, H. H. 1915. Growth of parts and systems of the body in weight. In The Rat, Data and Reference Tables. H. Donaldson, editor. Memoirs of the Wistar Institute of Anatomy and Biology \#6. 75.

30. Sterling, K. 1951. The turnover rate of serum albumin in man as measured by $\mathrm{I}^{131}$-tagged albumin. J. Clin. Invest. 30:1228-1237.

31. Janmey, P. A., T. P. Stossel, and S. E. Lind. 1986. Sequential binding of actin monomers to plasma gelsolin and its inhibition by vitamin D-binding protein. Biochem. Biophys. Res. Commun. 136:72-79.

32. Petrini, M., R. M. Galbraith, P. A. Werner, D. L. Emerson, and P. Arnaud. 1984. $G_{c}$ (vitamin D binding protein) binds to cytoplasma of all human lymphocytes and is expressed on B-cell membranes. Clin. Immunol. Immunopathol. 31:282-295.

33. Nestler, J. E., J. F. McLeod, M. A. Kowalski, J. F. Strauss III, and J. G. Haddad. 1987. Detection of vitamin D binding protein on the surface of cytotrophoblasts from human placentae. Endocrinology. In press.

34. McLeod, J. F., M. A. Kowalski, and J. G. Haddad. 1986. Characterization of a monoclonal antibody to human serum vitamin $\mathrm{D}$ binding protein $\left(G_{c}\right.$ globulin): Recognition of an epitope hidden in membranes of circulating monocytes. Endocrinology. 119:77-83.

35. Petrini, M., D. L. Emerson, and R. M. Galbraith. 1983. Linkage between surface immunoglobulin and cytoskeleton of B lymphocytes may involve $G_{c}$ protein. Nature (Lond.). 306:73-74.

36. Lind, S. E., D. B. Smith, P. A. Janmey, and T. P. Stossel. 1986. Role of plasma gelsolin and vitamin D-binding protein in clearing actin from the circulation. J. Clin. Invest. 78:736-742.

37. Korn, E. D. 1982. Actin polymerization and its regulation by proteins from nonmuscle cells. Physiol. Rev. 62:672-737.

38. Emerson, D. L., P. Arnaud, and R. M. Galbraith. 1983. Evidence of increased $\mathrm{G}_{\mathrm{c}}$-actin complexes in pregnant serum: a possible result of trophoblast embolism. Am. J. Reprod. Immunol. 4:185-189.

39. Lee, W. M., D. L. Emerson, P. A. Werner, P. Arnaud, P. Goldschmidt-Clermont, and R. M. Galbraith. 1985. Decreased serum groupspecific component protein levels and complexes with actin in fulminant hepatic necrosis. Hepatology. 5:271-275. 